\title{
Hubungan Antara Breastfeeding Self Efficacy (BSE) Pada Ibu Post Dengan Keberhasilan ASI
}

\section{Aryanti Wardiyah ${ }^{1}$, Lidya Arianti ${ }^{2}$, Anggita Widya Lestari $^{3}$}

\author{
${ }^{1}$ Dosen PSIK Universitas Malahayati Bandar Lampung \\ Email: aryanti@malahayati.ac.id \\ 2Dosen PSIK Universitas Malahayati Bandar Lampung \\ Email: lidya.arianti@yahoo.com \\ ${ }^{3}$ Perawat Pelaksana Puskesmas Satelit Kota Bandar Lampung \\ Email: angggita.widyalestari731@gmail.com
}

\section{THE CORRELATION BETWEEN BREASTFEEDING SELF EFFICACY (BSE) OF POST PARTUM WOMEN AND BREASFEEDING SUCCESS AT WORKING AREA OF SUMUR BATU HEALTH CENTER}

Background: A woman in her first breastfeeding practice is usually more sensitive regarding the condition of her infant. She is easily provoked by an assumption that the intake need of the infant cannot be met by the exclusive milk only. Moreover, at the initial time of breastfeeding, the woman breasts do not produce any milk but colostrum in small quantity. The woman with high expectation of baby optimal care without sufficient support may fall to oppressed situation in the postpartum period (postpartum blues). The woman suffering postpartum blues tends to give up breastfeeding in the initial time, experience breastfeeding difficulty, and low breastfeeding self-efficacy. The objective of this study was to identify the correlation between breastfeeding self-efficacy of postpartum women and breastfeeding success at working area of SumurBatu Health Cente.

Purpose: This study is a quantitative. The research design was descriptive study to investigate how and why a health phenomenon happened. The approach was retrospective.

Methods: The population consisted of 125 women registered at working area of SumurBatu Health Center since January to March 2019 with status of postpartum and or breastfeeding 6-12 month babies. The sample calculation was conducted with Solvin Formulation that resulting 96 respondents. The sampling technique was simple random sampling.

Results: The statistical test found that $p$ value was 0.001 or $p$ value $<0.05$ implying the correlation between breastfeeding self-efficacy of postpartum women and breastfeeding success at working area of SumurBatu Health Center in 2019. The health practitioners at the health center should educate the women about the importance of breastfeeding for 0-6 month babies through counseling and seminar

Conclusion: It is known that in the Work Area of the Sumur Batu Bandar Lampung Health Center in 2019, the majority of respondents had low Breastfeeding Self Efficacy totaling 40 respondents (41.7\%). It is expected that respondents will be able to increase knowledge about the importance of breastfeeding.

Keywords : Breastfeeding Self Efficacy (BSE), Breastfeeding Success

Aryanti Wardiyah ${ }^{1}$, Lidya Arianti ${ }^{2}$, Anggita Widya Lestari ${ }^{3}$

${ }^{1}$ Dosen PSIK Universitas Malahayati Bandar Lampung. Email: aryanti@malahayati.ac.id

2Dosen PSIK Universitas Malahayati Bandar Lampung. Email: lidya.arianti@yahoo.com

${ }^{3}$ Perawat Puskesmas Satelit Kota Bandar Lampung. Email: angggita.widyalestari731@gmail.com 


\section{INTISARI: HUBUNGAN ANTARA BREASTFEEDING SELF EFFICACY (BSE) PADA IBU POST PARTUM DENGAN KEBERHASILAN ASI DI WILAYAH KERJA PUSKESMAS SUMUR BATU}

Pendahuluan: Ibu dengan pengalaman pertama menyusui seringkali sangat sensitif terhadap segala sesuatu yang menyangkut keadaan bayinya, sehingga mudah terprovokasi dengan berbagai anggapan yang negatif seperti, bayi tidak akan cukup kenyang bila hanya mendapat ASI, apalagi di awal periode postpartum ibu hanya memproduksi kolostrum yang berjumlah sedikit atau bahkan belum mengeluarkan ASI. Ibu dengan harapan yang tinggi tentang perawatan bayi yang optimal, tetapi tidak ditunjang dengan pengetahuan dan dukungan yang adekuat dapat menyebabkan ibu jatuh pada kondisi stres selama periode postpartum (postpartum blues). Ibu yang mengalami gejala postpartum blues di awal periode postpartum mempunyai kecenderungan berhenti menyusui lebih awal, mengalami berbagai kesulitan dalam hal menyusui dan breastfeeding self effi cacy yang rendah.

Tujuan: Tujuan dalam penelitian ini adalah diketahui hubungan antara Breastfeeding Self Efficacy (BSE) dengan keberhasilan ASI pada ibu post partum di wilayah kerja Puskesmas Sumur Batu.

Metode: Jenis penelitian yang digunakan dalam penelitian ini adalah kuantitatif. Rancangan dalam penelitian ini menggunakan deskriptif yang artinya penelitian yang menggali bagaimana dan mengapa fenomena kesehatan itu terjadi, dengan menggunakan pendekatan retrospective. Populasi dalam penelitian ini adalah seluruh Ibu post partum dan ibu menyusui ASI 6-12 bulan yang ada di wilayah kerja puskesmas sumur batu Sumur Batu pada Bulan Januari-Maret yaitu sebanyak 125, dalam mengintung sampe menggunakan rumus slovin sehingga sampel minimum yang didapatkan berjumlah 96 responden. Dalam penelitian ini teknik sampling yang digunakan adalah simple random sampling.

Hasil:Berdasarkan hasil uji statistik, didapatkan p-value 0,001 atau p-value < 0,05 yang

Kesimpulan: Terdapat hubungan antara Breastfeeding Self Efficacy (BSE) dengan keberhasilan ASI pada ibu post partum di wilayah kerja Puskesmas Sumur Batu Tahun 2019. Diharapkan agar pihak Puskesmas dapat mengadakan pendidikan kesehatan dengan cara mengadakan seminar kesehatan dan memberikan konseling di poli kebidanan dengan sasaran ibu menyusui tentang pentingnya pemberian ASI pada bayi usia 0-6 bulan

Kata Kunci : Breastfeeding Self Efficacy (BSE) \& Keberhasilan Menyusui

Aryanti Wardiyah ${ }^{1}$, Lidya Arianti $^{2}$, Anggita Widya Lestari ${ }^{3}$

${ }^{1}$ Dosen PSIK Universitas Malahayati Bandar Lampung. Email: aryanti@malahayati.ac.id

2Dosen PSIK Universitas Malahayati Bandar Lampung. Email: lidya.arianti@yahoo.com

${ }^{3}$ Perawat Puskesmas Satelit Kota Bandar Lampung. Email: angggita.widyalestari731@gmail.com 


\section{PENDAHULUAN}

Penelitian yang terjadi dibeberapa negara berkembang mengungkapkan bahwa penyebab utama terjadinya gizi kurang dan hambatan pertumbuhan pada anakanak usia balita berkaitan denganrendahnya pemberian Air Susu Ibu (ASI). ASI tanpa bahan makanan lain dapat mencukupi kebutuhan pertumbuhan usiasampai sekitar 6 bulan. Selain ASI, pemberian Makan Pendamping Air Susu Ibu (MP-ASI) juga turut berperan dalam pertumbuhan dan perkembangan anak. Sebagaimana yang telah direkomendasikan oleh World Health Organization(WHO) dan diadopsi oleh seluruh negara di dunia termasuk Indonesia (Susanty dkk, 2012).

Presentasi pemberian ASI eksklusif pada bayi 0-6 bulan di Indonesia pada tahun 2013 sebesar $54,3 \%$, sedikit meningkat bila dibandingkan dengan tahun 2012 yang sebesar 48,6\%, di Provinsi Lampung 52,58\% pada tahun 2013 dan sedikit meningkat bila dibandingkan dengan tahun 2012 yang sebesar 29,24\% (Profil Kesehatan Indonesia,2013).

Sedangkan pencapaian ASI ekslusif di kota Bandar Lampung dari tahun ke tahun menunjukan hasil yang fluktuatif. Pada tahun 2011 tercatat pencapaian ASI ekslusif sebesar $65,1 \%$ dan di tahun berikutnya, 2012 terjadi peningkatan yaitu sebesar 67,93\% namun di tahun 2013 sampai bulan agustus pencapaian pemberian ASI ekslusif mengalami penurunan yaitu hanya sebesar $64,55 \%$. Angka ini bila dibandingkan dengan target nasional masih di bawah target yang di inginkan (80\%) (Profil Kesehatan Kota Bandar Lampung, 2013).
Di dapat dari penelitian yang di lakukan oleh Trisnawati pada tahun 2010 hasil penelitiannya yaitu Masih rendahnya ibu-ibu yang menyusui bayinya secara ekslusif juga dapat terlihat dari hasil penelitian yang dilakukan di Jakarta terhadap 854 bayi didapatkan bahwa hanya $29,9 \%$ bayi yang mendapatkan sampai 3 bulan. kemudian menurun menjadi $17 \%$ pada usia 4-6 bulan. Alasan ibu-ibu berhenti menyusui adalah 28\% karea bekerja 32\% karena mengeluh ASI sedikit, 16\% karena iklan ,4\% karena ingin modern.

Penelitian yang dilakukan oleh Handayani et al (2010) membuktikan bahwa ada hubungan yang erat antara dukungan sosial, pengetahuan, sikap dan self efficacy dengan perilaku menyusui.

Dalam penelitian ini peneliti memilih puskesmas Sumur Batu sebagai objek penelitian, di karnakan puskesmas Sumur Batu merupakan Puskesmas dengan jumlah bayi yang di beri ASI Eksklusif paling sedikit di seluruh Kota Bandar Lampungdari jumlah bayi yang di targetkan, di bandingkan puskesmas lainnya. Dua tahun belakangan ini puskesmas tersebut memiliki persentase paling sedikit yaitu di tahun 2016 dengan jumlah bayi 158 dan yang terealisasikan hanya $43 \quad(27,2 \%)$ yang di beri ASI Eksklusif, di tahun berikutnya 2017 dengan jumlah bayi 142 dan yang terealisasikan hanya $40(28,2 \%)$ yang di beri ASI Eksklusif. (Dinas Kesehatan Kota Bandar Lampung).

Sedangkan di Bandar
Lampung pada tahun 2017
pencapaian ASI Eksklusif adalah $62 \%$
tertinggi di puskesmas kebon jahe
sebesar $100 \%$ dan terendah berada
di puskesmas Sumur Batu yaitu

Aryanti Wardiyah ${ }^{1}$, Lidya Arianti ${ }^{2}$, Anggita Widya Lestari ${ }^{3}$

${ }^{1}$ Dosen PSIK Universitas Malahayati Bandar Lampung. Email: aryanti@malahayati.ac.id

2Dosen PSIK Universitas Malahayati Bandar Lampung. Email: lidya.arianti@yahoo.com

${ }^{3}$ Perawat Puskesmas Satelit Kota Bandar Lampung. Email: angggita.widyalestari731@gmail.com 
hanya 28,2\% (Profil Kesehatan Kota Bandar Lampung, 2018). Berdasarkan sasaran program Puskesmas Sumur Batu Kota Bandar Lampung pada tahun 2016 pencapaian ASI Eksklusif mencapai $43,2 \%$ dan mengalami penurunan pada tahun 2017 mencapai $28,2 \%$ masih di bawah target sebesar $44 \%$ (Profil Puskesmas Sumur Batu Kota Bandar Lampung).

Pada bulan januari-maret 2019ibu post partum dan ibu menyusui ASI 0-6 bulan yang berada di wilayah kerja puskesmas sumur batuberjumlah 96 ibu - ibu artinya dengan rata - rata sebanyak $32 \mathrm{ibu}$ post partum perbulannya. Data presurvei yang dilakukan pada 10 ibu post partum di dapatkan hasil 8 ibu tidak menyusui secara

\section{METODE PENELITIAN}

Jenis penelitian yang digunakan dalam penelitian ini adalah kuantitatif . Penelitian dilakukan pada tanggal 20-30 Juni 2019, di wilayah kerja Puskesmas Sumur Batu Bandar Lampung. Desain penelitian yang digunakan penelitian deskriptif. Populasi dalam penelitian ini adalah seluruh Ibu post partum dan ibu menyusui ASI 6-12 bulan yang ada di wilayah kerja puskesmas sumur batu Sumur Batu pada Bulan Januari-Maret yaitu sebanyak 125. Penelitian ini menggunakan teknik sampling yang digunakan adalah simple random sampling.

Teknik pengambilan data secara observasi Observasi yaitu dengan teknik yang digunakan untuk pengumpulan data dengan melakukan pengamatan dan pencatatan secara sistematik terhadap gejala yang tampak pada objek penelitian yaitu pada Posyandu Poskeskel Sumur
Batu,Bandar Lampung. Data yang diperoleh dari penelitian ini didapatkan langsung dari pengisian kuisioner (angket) yang ditujukan kepada responden tentang tanggapan atau pandangan tentang Hubungan Breasfeeding Self Efficacydenga Persepsi Ketidak Kucupan ASI pada Ibu Post Partum di Puskel Sumur Batu,Bandar Lampung. Berdasarkan uji validitas oleh Fian Anggia Pratidina (2017) diketehui bahwa nilai $r$ table untuk 20 responden adalah 0,44 sedangkan nilai $r$ hitung untuk variabel Breasfeeding self eficacy adalah 0.498-0,781, sehingga $r$ hitung > $r$ table atau 0,498$0,781>0,44$, sehingga kuesioner yang akan peneliti gunakan sudah teruji nilai validitasnya.

Dalam melakukan perhitungan Alpha, digunakan alat bantu program reliabel yaitu SPSS for Windows 18 dengan menggunakan model Alpha.

\section{HASIL PENELITIAN DAN \\ PEMBAHASAN \\ Hasil Penelitian \\ Analisis Univariat \\ Karateristik Responden \\ Usia Responden}

Tabel 1.

Distribusi Frekuensi Usia Responden

Di Wilayah Kerja Puskesmas Sumur

Bat Bandar Lampungn Tahun 2019

\begin{tabular}{ccc}
\hline $\begin{array}{c}\text { Usia } \\
\text { Responden }\end{array}$ & Frekuensi & $\begin{array}{c}\text { Persentase } \\
(\%)\end{array}$ \\
\hline $\begin{array}{c}22-28 \\
\text { Tahun }\end{array}$ & 80 & 83,3 \\
\hline $\begin{array}{c}29-35 \\
\text { Tahun }\end{array}$ & 16 & 16,7 \\
\hline Jumlah & 96 & $\mathbf{1 0 0 , 0}$ \\
\hline
\end{tabular}

Aryanti Wardiyah ${ }^{1}$, Lidya Arianti $^{2}$, Anggita Widya Lestari ${ }^{3}$

${ }^{1}$ Dosen PSIK Universitas Malahayati Bandar Lampung. Email: aryanti@malahayati.ac.id

${ }^{2}$ Dosen PSIK Universitas Malahayati Bandar Lampung. Email: lidya.arianti@yahoo.com

${ }^{3}$ Perawat Puskesmas Satelit Kota Bandar Lampung. Email: angggita.widyalestari731@gmail.com 
Berdasarkan tabel 1, diketahui bahwa Di Wilayah Kerja Puskesmas Sumur Batu Bandar Lampung Tahun 2019, sebagian besar responden berusia 22 - 28 Tahun yang berjumlah 80 responden $(83,3 \%)$.

\section{Pendidikan}

Tabel 2.

Distribusi Frekuensi Pendidikan Di Wilayah Kerja Puskesmas Sumur Batu Bandar Lampung Tahun 2019

\begin{tabular}{ccc}
\hline Pendidikan & Frekuensi & $\begin{array}{c}\text { Persentase } \\
\text { (\%) }\end{array}$ \\
\hline D3 & 4 & 4.2 \\
\hline S1 & 7 & 7.3 \\
\hline SD & 9 & 9.4 \\
\hline SMA & 44 & 45.8 \\
\hline SMP & 32 & 33.3 \\
\hline Jumlah & 96 & 100,0 \\
\hline
\end{tabular}

Berdasarkan tabel 2, diketahui bahwa Di Wilayah Kerja Puskesmas Sumur Batu Bandar Lampung Tahun 2019, sebagian besar responden mempunyai pendidikan SMA yang berjumlah 44 responden $(45,8 \%)$.

\section{Pekerjaan}

Tabel 3.

Distribusi Frekuensi Pekerjaan Di Wilayah Kerja Puskesmas Sumur Batu Bandar Lampung

Tahun 2019

\begin{tabular}{ccc}
\hline Pekerjaan & Frekuensi & $\begin{array}{c}\text { Persentase } \\
\text { (\%) }\end{array}$ \\
\hline Buruh & 7 & 7.3 \\
\hline IRT & 38 & 39.6 \\
\hline PNS & 11 & 11.5 \\
\hline Swasta & 22 & 22.9 \\
\hline Wiraswasta & 18 & 18.8 \\
\hline Jumlah & 96 & 100,0 \\
\hline
\end{tabular}

Berdasarkan tabel 3, diketahui bahwa Di Wilayah Kerja Puskesmas Sumur Batu Bandar Lampung Tahun 2019, sebagian besar responden mempunyai pekerjaan sebagai IRT yang berjumlah 38 responden $(39,6 \%)$.

\section{Analisis Univariat Breastfeeding Self Efficacy} Tabel 4.

Distribusi Frekuensi Breastfeeding Self Efficacy Di Wilayah Kerja Puskesmas Sumur Batu Bandar Lampung Tahun 2019

\begin{tabular}{ccc}
\hline $\begin{array}{c}\text { Breastfeeding } \\
\text { Self Efficacy }\end{array}$ & Fre & $\begin{array}{c}\text { Persentase } \\
\text { (\%) }\end{array}$ \\
\hline Rendah & 40 & 41.7 \\
\hline Sedang & 28 & 29.2 \\
\hline Tinggi & 28 & 29.2 \\
\hline Jumlah & 96 & 100,0
\end{tabular}

Berdasarkan tabel 4, diketahui bahwa Di Wilayah Kerja Puskesmas Sumur Batu Bandar Lampung Tahun 2019, sebagian besar responden mempunyai Breastfeeding Self Efficacy yang rendah berjumlah 40 responden $(41,7 \%)$.

\section{Keberhasilan Menyusui}

Tabel 5.

Distribusi Frekuensi Keberhasilan Menyusui Di Wilayah Kerja

Puskesmas Sumur Batu Bandar Lampung Tahun 2019

\begin{tabular}{lcl}
\hline $\begin{array}{l}\text { Keberhasilan } \\
\text { Menyusui }\end{array}$ & Fre & Persentase (\%) \\
\hline ASI Eksklusif & 28 & 29.2 \\
\hline $\begin{array}{l}\text { ASI } \\
\text { Predominan }\end{array}$ & 19 & 19.8 \\
\hline Non ASI & 49 & 51.0 \\
\hline Jumlah & 96 & 100,0 \\
\hline
\end{tabular}

Berdasarkan tabel 5, diketahui bahwa Di Wilayah Kerja Puskesmas Sumur Batu Bandar Lampung Tahun 2019, sebagian besar responden memberikan Non ASI yang berjumlah 49 responden $(51,0 \%)$.

Aryanti Wardiyah ${ }^{1}$, Lidya Arianti ${ }^{2}$, Anggita Widya Lestari ${ }^{3}$

${ }^{1}$ Dosen PSIK Universitas Malahayati Bandar Lampung. Email: aryanti@malahayati.ac.id

2Dosen PSIK Universitas Malahayati Bandar Lampung. Email: lidya.arianti@yahoo.com

${ }^{3}$ Perawat Puskesmas Satelit Kota Bandar Lampung. Email: angggita.widyalestari731@gmail.com 
Analisa Bivariat

Untuk mengetahui hubungan antara Breastfeeding Self Efficacy (BSE) dengan keberhasilan ASI pada ibu post partum di wilayah kerja Puskesmas Sumur Batu Tahun 2019, maka digunakan analisa bivariat, yaitu:

\section{Hubungan Antara Breastfeeding Self Efficacy Dengan Keberhasilan ASI pada Ibu Post Partum}

Berdasarkan tabel 6, diketahui bahwa Di Wilayah Kerja Puskesmas Sumur Batu Bandar Lampung Tahun 2019, terdapat Breastfeeding Self Efficacy (BSE) rendah berjumlah 40 responden, dimana yang memberikan ASI Eksklusif berjumlah 7 responden $(17,5 \%)$, ASI Predominan berjumlah 9 responden $(22,5 \%)$, dan yang Non ASI berjumlah 24 responden $(60,0 \%)$, terdapat Breastfeeding Self Efficacy (BSE) yang sedang berjumlah 28 responden, dimana yang memberikan ASI Eksklusif berjumlah 4 responden (14,3\%), ASI Predominan berjumlah 8 responden $(28,6 \%)$, dan yang Non ASI berjumlah 16 responden $(57,1 \%)$, sedangkan Breastfeeding Self Efficacy (BSE) yang tinggi berjumlah 28 responden, dimana yang memberikan ASI Eksklusif berjumlah 17 responden $(60,7 \%), \quad$ ASI Predominan berjumlah 2 responden $(7,1 \%)$, dan yang Non ASI berjumlah 9 responden $(32,1 \%)$.

Berdasarkan hasil uji statistik, didapatkan p-value 0,001 atau $p$-value $<0,05$ yang artinya terdapat hubungan antara Breastfeeding Self Efficacy (BSE) dengan keberhasilan ASI pada ibu post partum di wilayah kerja Puskesmas Sumur Batu Tahun 2019.

\section{Pembahasan Univariat Breastfeeding Self Efficacy}

Berdasarkan hasil penelitian, diketahui bahwa Di Wilayah Kerja Puskesmas Sumur Batu Bandar Lampung Tahun 2019, sebagian besar responden mempunyai Breastfeeding Self Efficacy yang rendah berjumlah 40 responden $(41,7 \%)$.

Self-efficacy adalah keyakinan yang dimiliki seseorang mengenai kopetensi atau efektifitasnya dalam area tertentu (Hirawan, 2011). Secara umum selfefficacy adalah penilaian seseorang terhadap dirinya sendiri atau tingkat keyakinan mengenai seberapa besar kemampuannya dalam mengerjakan suatu tugas tertentu untuk mencapai hasil tertentu. Disimpulkan bahwa selfefficacy merupakan tingkat keyakinan seseorang terhadap dirinya sendiri mengenai kemampuannya dalam mengerjakan tugas untuk mencapai hasil tertentu.

Penelitian Lina Handayani, dkk tentang The association between breastfeeding technique and knowledge with exclusive breastfeeding, menyebutkan bahwa Ibu dengan tingkat pengetahuan rendah lebih banyak (57\%) begitu juga pengetahuan teknik menyusui $(52,1 \%)$. Ada hubungan antara pengetahuan dengan pemberian ASI eklsusif $(p=0,006)$ dan ada hubungan antara teknik menyusui dengan pemberian ASI ekslusif $(p=0,002)$.

\section{Keberhasilan ASI Pada Ibu Post Partum.}

Berdasarkan hasil penelitian, diketahui bahwa Di Wilayah Kerja Puskesmas Sumur Batu Bandar Lampung Tahun 2019, sebagian

Aryanti Wardiyah ${ }^{1}$, Lidya Arianti $^{2}$, Anggita Widya Lestari ${ }^{3}$

${ }^{1}$ Dosen PSIK Universitas Malahayati Bandar Lampung. Email: aryanti@malahayati.ac.id

2Dosen PSIK Universitas Malahayati Bandar Lampung. Email: lidya.arianti@yahoo.com

${ }^{3}$ Perawat Puskesmas Satelit Kota Bandar Lampung. Email: angggita.widyalestari731@gmail.com 
besar responden memberikan Non ASI yang berjumlah 49 responden $(51,0 \%)$.

Air Susu Ibu (ASI) adalah suatu emulsi lemak dalam larutan protein, laktosa dan garam-garam anorganik yang sekresi oleh kelenjar mamae ibu, yang berguna sebagai makanan bagi bayinya (Theresia, 2007). Sedangkan ASI eksklusif atau lebih tepat pemberian ASI secara eksklusif adalah bayi hanya diberi ASI saja, tanpa pemberian cairan lain seperti susu formula, jeruk, madu, air teh, air putih dan tanpa tambahan makanan padat seperti pisang, pepaya, bubur susu, biskuit, bubur nasi dan tim (Purwanti, 2012).

\section{Pembahasan Bivariat Hubungan Antara Breastfeeding Self Efficacy Dengan Keberhasilan ASI pada Ibu Post Partum}

Berdasarkan asil penelitian, diketahui bahwa Di Wilayah Kerja Puskesmas Sumur Batu Bandar Lampung Tahun 2019 hasil uji statistik, didapatkan $\mathrm{p}$-value 0,001 atau $p$-value < 0,05 yang artinya terdapat hubungan antara Breastfeeding Self Efficacy (BSE) dengan keberhasilan ASI pada ibu post partum di wilayah kerja Puskesmas Sumur Batu Tahun 2019. Keberhasilan dalam memberikan ASI secara eksklusif harus ditunjang dengan tindakan menyusui yang efektif. Tindakan menyusui efektif merupakan proses interaktif antara ibu dan bayi dalam rangka pemberian ASI secara langsung dari payudara ibu ke bayi dengan cara yang benar dan kuantitas yang memadai untuk memenuhi kebutuhan ibu dan bayi. Tindakan menyusui yang tidak efektif mengindikasikan posisi menyusui yang masih salah, perlekatan yang tidak benar, hisapan bayi yang kurang optimal dan milktransfer yang tidak adekuat. Ketidakmampuan dalam menyusui secara efektif menimbulkan berbagai masalah selama menyusui seperti puting lecet, bayi terus menangis karena masih lapar dan pada akhirnya ibu akan tertarik untuk mencoba memberikan susu formula pada bayi. Pemberian susu formula berdampak negatif pada bayi antara lain risiko pencemaran bakteri, imunitas yang tidak adekuat, sehingga meningkatkan risiko diare dan infeksi saluran pernapasan akut dan kemungkinan alergi protein susu sapi (Siregar, 2014).

Faktor yang dapat mendukung tindakan menyusui efektif antara lain keyakinan diri bahwa mampu untuk menyusui secara efektif. Self efficacy merupakan rasa percaya diri yang dimiliki oleh seseorang terhadap suatu hal yang belum dilakukan yang dapat meningkatkan motivasi (Bandura, 2014). Breastfeeding self efficacy merupakan rasa percaya diri yang dimiliki oleh ibu dalam hal menyusui yang dapat menjadi predictor apakah ibu akan memutuskan untuk menyusui, sebesar apa upaya yang akan dilakukan untuk menyusui, apakah mempunyai pola pikir membangun atau merusak dan bagaimana cara merespons berbagai masalah dan kesulitan selama menyusui (Hirawan, 2011). Hal tersebut berarti semakin tinggi breastfeeding self efficacy, semakin keras usaha ibu agar dapat berhasil menyusui, begitu pun sebaliknya.

Menurut penelitian Retnayu Pradanie tentang Paket Dukungan Terhadap Breastfeeding Self Efficacy Dan Keberhasilan Menyusui

Aryanti Wardiyah ${ }^{1}$, Lidya Arianti ${ }^{2}$, Anggita Widya Lestari ${ }^{3}$

${ }^{1}$ Dosen PSIK Universitas Malahayati Bandar Lampung. Email: aryanti@malahayati.ac.id

2Dosen PSIK Universitas Malahayati Bandar Lampung. Email: lidya.arianti@yahoo.com

${ }^{3}$ Perawat Puskesmas Satelit Kota Bandar Lampung. Email: angggita.widyalestari731@gmail.com 
Pada Ibu Postpartum, menyebutkan bahwa Skor breastfeeding self efficacy pada kelompok perlakuan meningkat lebih tinggi dibandingkan kelompok kontrol. Namun, uji hipotesis menunjukkan bahwa tidak ada perbedaan antara kelompok perlakuan dan kontrol setelah diberikan intervensi paket dukungan menyusui ( $p=0,104)$. Tidak ada hubungan yang signifi kan antara breastfeeding self efficacy dan tindakan menyusui efektif $(p=$ 0,976). Analisis dan Diskusi: Faktor yang mempengaruhi breastfeeding self effi cacy tidak hanya sumber informasi tapi juga pekerjaan dan tingkat pendidikan. Breastfeeding self efficacy bukan merupakan faktor pembentuk tindakan menyusui yang efektif. Sehingga penelitian ini tidak sejalan dengan penelitian yang dilakukan oleh Retnayu Pradanie.

\section{KESIMPULAN}

Terdapat hubungan antara Breastfeeding Self Efficacy (BSE) dengan keberhasilan ASI pada ibu post partum di wilayah kerja Puskesmas Sumur Batu Tahun 2019.

\section{SARAN}

Diharapkan agar pihak
Puskesmas dapat mengadakan
pendidikan kesehatan dengan cara
mengadakan seminar kesehatan dan
memberikan konseling di poli
kebidanan dengan sasaran ibu
menyusui tentang pentingnya
pemberian ASI pada bayi usia 0-6
bulan

\section{DAFTAR PUSTAKA}

Aprina, Anita. (2018). Riset Keperawatan.

Albery IP, Munafo M. (2011). Psikologi Kesehatan Panduan lengkap dan komprehensif bagi studi psikologi kesehatan. Yogyakarta: Palmall.

Awano, M, Shimada K. Development and evaluation of a self care program on breastfeeding in Japan: a quasi-experimental study. International

Breastfeeding. 2010 ; 5 (9):110.

Blyth, R, Creedy, DK, Dennis, C-L, Moyle, W, Pratt, J \& Vries, SMD. (2012). effect of maternal confi dence on breastfeeding duration: an application of breastfeeding self-effi cacy theory, birth: Issues in Prenatal Care, vol 29, no. 4, hal. 278-284.

Britton, (2017). Maternal SelfConcept and Breastfeeding. journals.sagepub

Dinkes. (2017). Dinas Kesehatan Kota Bandar Lampung.

Dennis, CL \& McQueen, K. (2009). 'The relationship between infant-feeding outcomes and postpartum depression: a qualitative systematic review', Pediatrics, vol. 123, no. 4, pp. e736- e751.

Dennis, C. L. (2010). The breastfeeding self-efficacy scale : psychometric assessment of the short form. JOGNN. 2010:6:734-744

Khusnul,U. F (2016). Edukasi Prenata Dalam Upaya Penigkatan Breasfeeding Self. Jurnal Ners dan kebidanan. Agustus Vol. 3, No. 2.

Aryanti Wardiyah ${ }^{1}$, Lidya Arianti ${ }^{2}$, Anggita Widya Lestari ${ }^{3}$

${ }^{1}$ Dosen PSIK Universitas Malahayati Bandar Lampung. Email: aryanti@malahayati.ac.id

2Dosen PSIK Universitas Malahayati Bandar Lampung. Email: lidya.arianti@yahoo.com

${ }^{3}$ Perawat Puskesmas Satelit Kota Bandar Lampung. Email: angggita.widyalestari731@gmail.com 
Komalasari. (2012). Analisis Faktorfaktor Yang Berhubungan Dengan Persepsi ketidakcukupan ASI Pada Ibu Yang Memiliki Bayi Umur 0-6 Bulan di Wilayah Kerja Puskesmas Pancoran Mas Kota DepokTahun 2011.

McQueen, K. A., Dennis, C. L., Stremler, R., Norman, C. D. (2011). A pilot randomized controlled trial of a breastfeeding self efficacy intervention with primiparous mothers, JOGNN, vol 40, hal. 35-46.

Monika. F.B. (2018).Buku Pintar ASI dan Menyusui. Jakarta: Noura Books (MizanGrup), 2014.

Notoatmodjo, S. (2010). Metodologi PenelitianKesehatan. Jakarta ; PT RinekaCipta.

Pratidina, A., Fian. (2017). Breasfeeding Self Efficacy Pada Ibu Post Partu Di RS PKU Muhammadiyah Gomong.

Pradanie, R. (2015). Paket Dukungan Terhadap Breastfeeding Self Efficacy Dan Keberhasilan Menyusui Pada Ibu Postpartum. Jurnal Ners, 10/1(April), 20-29.

Pratidina, F. A. (2017). Breastfeeding Self Efficacy Pada Ibu Post Partum Di Rs Pku Muhammadiyah Gombong.

Rasyad, A. S., \& Sujatno, H. R. M. (2012). Efikasi Diri Dan Lama Pemberian Air Susu Ibu Saja Selama 2 Bulan Postpartum, 9(2), 7-16.
Rahayu, D. (2018). Hubungan Breasfeeding Self Efficacy Dengan Keberhasilan Pemberian ASI Ekslusif. Jurnal Ilmu Kesehatan. November Vol. 7, No. 1.

Sulistyaningsih. (2016). Metodologi Penelitian Kebidanan: Kuantitatif-kualitatif Yogyakarta. Graha Ilmu.

Spaulding, D.M., Gore, R. (2009). Breastfeeding self-efficacy in women of african descent. JOGNN, 38, 230-243; 2009. doi : $10.1111 / j . \quad 1552$

Walyani,E. S. S., Purwoastuti,E. (2015). Asuhan Kebidanan Masa Nifas dan Menyusui.Yogyakarta :PT Pustaka Baru.

Aryanti Wardiyah ${ }^{1}$, Lidya Arianti ${ }^{2}$, Anggita Widya Lestari ${ }^{3}$

${ }^{1}$ Dosen PSIK Universitas Malahayati Bandar Lampung. Email: aryanti@malahayati.ac.id

2Dosen PSIK Universitas Malahayati Bandar Lampung. Email: lidya.arianti@yahoo.com

${ }^{3}$ Perawat Puskesmas Satelit Kota Bandar Lampung. Email: angggita.widyalestari731@gmail.com 